\title{
Nasal Angiofibroma in a Female: A Rare Case Report
}

\author{
Liza D. Korambil ${ }^{1 *}$ and BP Katakwar ${ }^{2}$ \\ ${ }^{1}$ Specialist ENT, UAE \\ ${ }^{2}$ Retd Professor and Head, Department of ENT, Indira Gandhi Government Medical College, India
}

Submission: March 06, 2017; Published: March 13, 2017

*Corresponding author: Liza D. Korambil, Specialist ENT, UAE, Tel: +971509178991, Email: lizadeepak@gmail.com

\begin{abstract}
An atypical and very rare clinical case of nasal angiofibroma in a 19 years old female who presented with recurrent epistaxis and nasal blockage. The tumour was located in right nostril with attachment to right lateral wall. Computed tomography scan was done. The patient underwent surgery with excision of mass in right nasal cavity. The histopathological examination confirmed the diagnosis of angiofibroma. Angiofibroma in a female is exceptional as we have verified through a literature review.
\end{abstract}

Keywords: Angiofibroma; Epistaxis; Female

\section{Introduction}

Angiofibroma is a benign vascular swelling arising in the nasopharynx in the region of sphenopalatine foramen of prepubertal and adolescent males and exhibiting a strong tendency to bleed [1]. The age of presentation varies between 7 and 19 years [2], with isolated patients presenting earlier or later. We present the clinical case of a 19 years old girl with repetitive epistaxis and nasal blockage due to highly vascularised mass that turned out to be an angiofibroma histologically.

\section{Case Report}

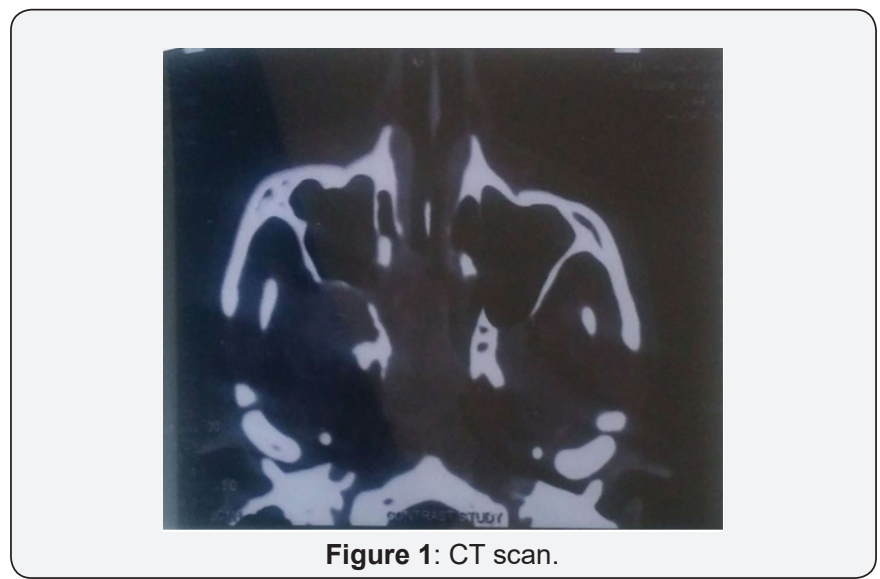

A female patient aged 19 years presented to the hospital with right nasal obstruction and bleeding from right nostril on and off since one month. Bleeding was 2-3 times and only few drops with trivial trauma. On examination, there was splaying of right nasal bone, and on anterior rhinoscopy, a reddish mass was seen in right nasal cavity. X-ray paranasal sinuses-Water's view revealed haziness in right maxillary sinus and in right nasal cavity which gave an impression that the polypoidal mass was arising from lateral wall of right nasal cavity or maxillary antrum. CT scan of the nose and PNS revealed multiple polyps in right maxillary antrum with mucosal thickening involving the ipsilateral ostiomeatal complex and a vascular mass in right nasal cavity attached to the lateral wall (Figure 1).

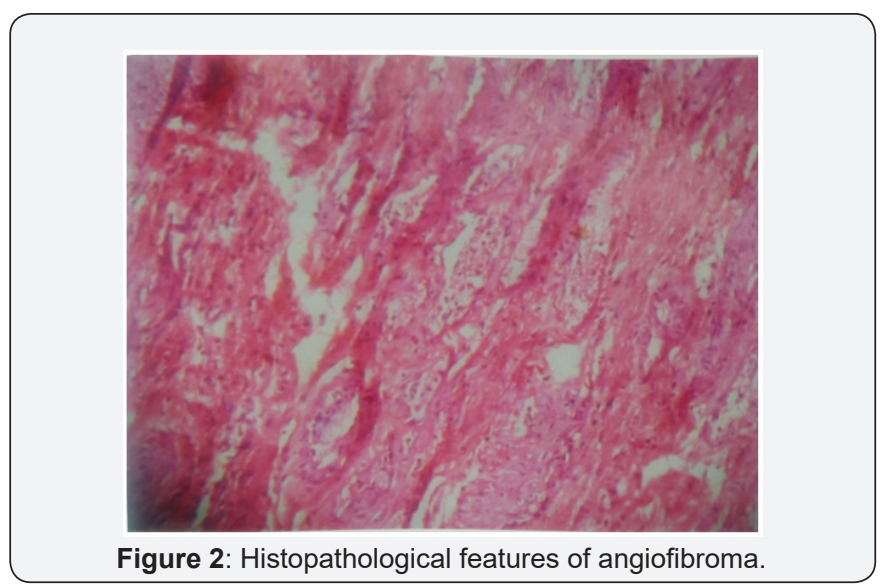

Angiography and embolisation facility is not available at our institute and patient was too poor to get it done from outside. The initial suspected diagnosis was a vascular tumour of right nasal fossa. The case was taken up and the patient was investigated thoroughly for general anaesthesia. Under general anaesthesia, 
the mass was excised by lateral rhinotomy. There was profuse bleeding during the surgery which was controlled with pressure packing. The bleeding stopped after complete removal of mass. The postoperative period was uneventful. Histopathological diagnosis was consistent with features of angiofibroma (Figure 2).

\section{Discussion}

Numerous theories have attempted to explain the etiology of nasal angiofibromas. Recent investigations consider these to be vascular malformations, but many aspects are still not sufficiently clarified [3]. Oestrogen is also said to have a protective effect. Angiofibromas are typical tumours found almost exclusively in adolescent males with mean age of presentation at around 14 years. Juvenile angiofibroma usually presents with profuse, recurrent, spontaneous nasal bleeding and nasal obstruction. There is stasis of secretions and sepsis, followed by hyposmia or anosmia. The voice acquires a nasal intonation. Blockage of eustachian tube may result leading to deafness and otalgia. Anterior rhinoscopy may reveal a nasal mass and abundant mucopurulent secretions and deviation of nasal septum to opposite side. Posterior rhinoscopy may show a red mass filling the nasopharynx. When the disease is extensive, the nasal bones are often splayed out. There may be trismus. Proptosis occurs when orbital fissures have been penetrated. The classical frog face is the ultimate picture of massive escape of disease.

A full clinical history, a nasal endoscopy and complementary tests or explorations, of which angiography is fundamental to provide us with images of the obvious vascularisation of the tumour, are indispensable for diagnosis, in our opinion $[4,5]$. The treatment that we carried out was surgical but a preoperative embolisation of the lesion is highly recommended [5]. In our case, embolisation of lesion was not possible. Endoscopic surgery [6] is another option recommended for angiofibroma limited to the nasal fossae but here the possibility of intense haemorrhaging might cause the procedure to fail. In addition to malignant tumours, differential diagnosis must be made with angiomatous polyps, haemangiopericytoma, haemangiomas, angiomyolipoma, leiomyomas, paragangliomas, fibrous dysplasia, fibroma, neuroectodermal tumours, inverted papilloma, ameloblastoma, chordomas and chondroblastomas, amongst other pathologies of the paranasal fossae and sinuses [7].

\section{Conclusion}

The reported case is different from a classical case of juvenile nasopharyngeal angiofibroma in many aspects. The disease occurred in a female which is a rarity. An atypical localisation, the mass was not arising from sphenopalatine foramen which is the commonest site of origin of angiofibroma. Our diagnosis was confirmed by histopathological examination and was revised by the Department of Pathology at our hospital. Follow up of patient is regular by means of nasal endoscopy to ensure the absence of tumour persistence or recurrence.

\section{References}

1. Scott-Brown ( $6^{\text {th }}$ edn), volume 5: Larynx and head neck.

2. Martin, Ehrlich and Abel (1948).

3. Schick B, Plinkert AC, Prescher A (2002) Etiology of angiofibromas: Reflection on their specific vascular component. Laryngorhinootologie 81(4): 280-284.

4. Chandler J (1984) Nasopharyngeal Angiofibromas: Staging and Management. Ann Otol Rhinol 93(4 Pt 1): 322-329.

5. Jamal MN (1994) Imaging and management of angiofibroma. Eur Arch Otorhinolaryngol 251(4): 241-245.

6. Han D, Chen X, Wang J (1998) Endoscopic nasal surgery in treatment of nasopharyngeal angiofibroma. Zhonghua Er bi Yan Hou Ke Za Zhi 33(6): 358-360.

7. (2004) Acta otorhinolaringol esp 55: 195-197.

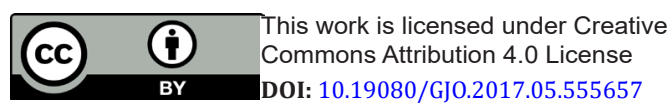

\section{Your next submission with Juniper Publishers will reach you the below assets}

- Quality Editorial service

- Swift Peer Review

- Reprints availability

- E-prints Service

- Manuscript Podcast for convenient understanding

- Global attainment for your research

- Manuscript accessibility in different formats ( Pdf, E-pub, Full Text, Audio)

- Unceasing customer service

Track the below URL for one-step submission https://juniperpublishers.com/online-submission.php 